\title{
KAPASITAS KULTURAL PEMIMPIN INFORMAL DALAM MEWUJUDKAN MASYARAKAT HARMONIS
}

\author{
Entoh Tohani \\ Fakultas Ilmu Sejarah Universitas Negeri Yogyakarta
}

\begin{abstract}
Abstrak
Pendidikan multikultural diselenggarakan sebagai upaya menciptakan kehidupan masyarakat yang terbebas dari ketidakadilan atau disfungsi sosial. Keberhasilan pencapain tujuan pendidikan multukultural di masyarakat dipengaruhi oleh keberfungsian pemimpin informal. Pemimpin informal memiliki pengaruh dan posisi strategis dalam menciptakan kehidupan masyarakat yang harmonishumanis. Oleh karena itu, pemimpin informal perlu menjalankan berbagai pendekatan pendidikan multikultural secara optimal sebagai individu yang paling berperan aktif dalam penyelenggaraan pendidikan mutlikultural di masyarakat. Fungsi pemimpin dimaksud tidak akan tercapai apabila kapasitas cultural pemimpin informal tidak dapat terwujud. Oleh karena itu, kapasitas cultural perlu dikembangkan melalui berbagai intervensi.
\end{abstract}

Kata kunci: pendidikan multikultural, pemimpin informal, kapasitas cultural

\section{CULTURAL CAPASITIES OF INFORMAL LEADERS IN REALIZING HARMONIOUS SOCIETIES}

\begin{abstract}
Abstact
Multicultural education is managed as an effort to create a society free from injustice or sosial dysfunction. The successful achievement of muticultural education goals in communities is affected by the function of informal leaders. Informal leaders have influence and strategic position in creating a harmonious and humanistic community. Therefore, the informal leaders need to run a variety of multicultural education approaches optimally as individuals who are most active in providing multicultural education in community. This function will not be achieved if the cultural competencies of informal leaders cannot be realized. Therefore, cultural capacities needs to be developed through various interventions.
\end{abstract}

Keywords: multicultural education, informal leaders, cultural capaciy 


\section{PENDAHULUAN}

Tujuan pembangunan suatu masyarakat pada dasarnya diarahkan pada peningkatan mutu kehidupan warga masyarakat baik dalam bidang ekonomi, sosial-budaya maupun politik. Dalam bidang ekonomi, warga masyarakat diharapkan menjadi manusia yang produktif, mandiri, inovatif, dan memiliki sikap dan nilai berwirausaha. Dalam bidang sosial budaya, setiap warga negara diharapkan menjadi manusia yang memiliki kepribadian utuh, berkarakter baik dan memiliki perilaku positif dalam kehidupan bermasyarakat. Sedangkan dalam kehidupan politik, warga masyarakat diharapkan dapat berpartisipasi aktif dan positif dalam menyukseskan pembangunan bangsa, dan selalui melaksanakan dan menjaga perilaku demokratis, toleransi, dan kebersamaan dengan orang lain (Fegerlind \& Saha, 1983).

Dalam kehidupan nyata dewasa ini, banyak kenyataan yang menggambarkan bahwa tujuan pembangunan, khususnya dalam bidang sosial budaya belum tercapai optimal. Berbagai bentuk ketidakharmonisan dalam keseimbangan sistem sosial masyarakat saat ini, nampak terlihat dari berbagai informasi media massa yang menggambarkan terjadinya masalah sosial. Misalnya perlakuan perkelahian antar warga masyarakat, bentrokan antar para pendukung partai politik, perlakukan disparitas memperoleh kesempatan pendidikan pada kelompok miskin dan kelompok beruntung karena struktur sosial yang kaku dan hegemoni kepentingan tertentu, perlakukan anggota masyarakat yang tidak manusia terhadap kelompok masyarakat kurang beruntung baik fisik maupun mental, perlakukan tindak kekerasan terhadap suatu kelompok tertentu, dan lain sebagainya.
Setiap anggota masyarakat dapat berfungsi aktif dalam mengembangankan dan menjaga keharmonisan sosial. Salah satu pihak yang memiliki peran strategis dalam mencegah dan mengurangi tindakan-tindakan destruktif terhadap kesejahteraan sosial masyarakat adalah pemimpin informal. Pemimpin informal memiliki kedudukan yang cukup tinggi di masyarakatnya mengingat mereka adalah orangorang yang dipandang memiliki kapasitas atau keunggulan tertentu dibanding dengan warga masyarakat lainnya. Keberadaan pemimpin informal menjadi pintu masuk berbagai pengaruh positif maupun negative yang berasal dari lingkungan luar masyarakatnya. Dengan kata lain, pemimpin informal merupakan individu-individu yang berfungsi sebagai saluran dan agent pengembangan masyarakat.

Fungsi pemimpin informal dalam mewujudkan masyarakat yang harmonis, dalam kenyataan belum dapat berjalan optimal. Berbagai bentuk disharmoni dalam interaksi sosial dapat diakibatkan oleh perilaku pemimpin informal yang kurang dapat mewaspadai dan peka terhadap berbagai pengaruh negative yang masuk ke dalam masyarakat, pemahaman yang keliru yang dimilikinya mengenai kelompokkelompok sosial lain dan paham tersebut disebarluaskan kepada para pengikutnya, pemahaman mengenai superioritas kelompok yang dipandang lebih unggul dibanding kelompok lain, dan bahkan ketidakmauan terbuka terhadap kelompok sosial lain. Selain itu, pengetahuan yang minim terhadap keragaman, kekurang terbukaan pada perubahan, dan sikap enggan melakukan perubahan menjadi factor penghambat pula. Dalam hal ini, pemimpin informal masih belum 
dapat menjalankan kewajiban membentuk masyarakat yang adil, toleransi, saling menghargai, dan saling bekerja sama dalam struktur sosial yang heterogen. Oleh karena itu, menjadi suatu kewajiban untuk mengembangkan pemimpin informal menjadi individu-individu yang memiliki wawasan dan kapasitas multikultural.

\section{PEMBAHASAN}

\section{Pendidikan Multikultural untuk Keharmonisan}

Kehidupan masyarakat yang harmonis nampaknya nampaknya keadaan proses sosial yang tidak terdapat konfliks-konfliks sosial. Konfliks sosial menggambarkan adanya ketidakharmonisan dalam kehidupan bermasyarakat Konfliks sosial dimaknai sebagai suatu proses sosial antara dua orang atau lebih (bisa juga kelompok) dimana salah satu pihak berusaha menyingkirkan pihak lain dengan menghancurkannya atau membuatnya tidak berdaya (www.wikipedia.org). Menurut Webster (1966) istilah "conflict" di dalam bahasa aslinya berarti suatu "perkelahian, peperangan atau perjuangan"- yaitu berupa konfrontasi fisik antar beberapa pihak, dan berkembang kemudian dengan masuknya "ketidaksepakatan yang tajam atau oposisi atas berbagai kepentingan, ide, dan lain-lain (Pruitt and Rubin, 2004:9). Sedangkan Rummel menyatakan bahwa sosial conflict is then the confrontation of sosial powers. Konfliks sosial adalam konfrontasi kekuatankekuatan sosial (www.hawaii.edu). Dengan demikian dapat diartikan bahwa konfliks dapat bentuk konfrontasi fisik maupun konfrontasi aspek psikologis karena perbedaan antar kekuatan sosial.
Konfliks sosial dapat terjadi karena adanya 1) perbedaan pertimbangan antara pertimbangan idealistis dengan pertimbangan realistis, 2) adanya sikap frustasi dan cemburu sosial terhadap keberhasilan-keberhasilan orang lain, 3) tidak ada alternative-alternative atau aspirasi yang dapat diterima oleh semua pihak, atau tidak terwujudnya solusi integrative yang dapat menyepakatkan kepentingan kedua belah pihak, dan 4) adanya kondisi stabilitas yang dapat memicu konfliks (Puitt and Rubin, 2004:27-53). Terkait dengan ini, Rumlett menjelaskan bahwa konfliks terjadi karena ketidakseimbangan kekuatan (power) yang dimiliki para pihak yaitu coersive power, bargaining power, intellectual power, authrorative power, altruistic power, dan manipulative power (www.hawaii.edu).

Pendapata lain disampaikan oleh Sutoro Eko (2002:145) bahwa konfliks dapat terjadi antar kedua pihak dalam dimensi sturktural dan dimensi cultural. Dimensi structural merupakan perilku konfliks yang terjadi antara para pihak terkait dengan penyediaan dan pemerataan akses atau kesempatan dalam memanfaatkan sumberdaya masyarakat yang ada, atau adanya perlakukan-perlakuan tidak adil dari pihak satu terhadap pihakt lain. Dimensi cultural menekankan bahwan konfliks terjadi akibat adanya perbedaan-perbedaan aspek cultural, misalnya perbedaan kegiatan makan bersama dan komunikasi yang kurang kondusif. Mengingat bahaya konfliks sosial baik bahaya material maupun nonmaterial maka perlu diupaya solusi pemecahannya.

Konfliks sosial dapat diatasi dengan dua pendekatan yaitu: pertama pendekatan yang menekankan pada kekuasaan negara yang mana 
negera menggunakan powernya untuk mengatur dan mengontrol masyarakat, dan dalam perkembangannya pendekatan ini mengarah pada tindakan koersi dan represi negara terhadap pemerintah. Pendapatan kedua yaitu pendekatan yang menekankan pada partisipasi masyarakat. Pendekatan ini dilakukan dengan berlandaskan pada terbangunnya dialog atau kontrak sosial dalam prularisme masyarakat. Terkait dengan dua pendekatan ini, nampaknya di masyarakat untuk mewujudkan masyarakat yang harmonissejahtera, pengembangan pendidikan multikultural dalam masyarakat menjadi suatu upaya pembaharuan masyarakat.

Pendidikan multikultural sebagai pendekatan progresif untuk melakukan transformasi pendididikan secara holistic, memberikan kritik kelemahan-kelemahan, kegagalan-kegagalan dan diskriminasi yang terjadi dalam dunia pendidikan saat ini (Smith, 1998; dalam Zamrani, 2011:144). Layanan pendidikan selama ini kurang dapat dirasakan oleh kelompok masyarakat kurang beruntung; pendidikan lebih diorientasikan bagi warga masyarakat yang memiliki sumberdaya untuk memperolehnya; dan berbagai tindakan diskriminasi dalam proses pendidiakn sering terjadi. Ladson-Billings menyatakan bawah pendidikan multikultural sebagai bentuk pendidikan yang dapat dijadikan pondasi guna melakukan transformasi masyarakat dan menghilangkan penindasan dan ketidakadilan.

Pendapat lain sampaikan Banks (2002:1) bahwa pendidikan multikultural merupakan suatu pergerakan reformasi yang dirancang untuk membuat perubahan-perubahan besar dalam pendidikan anak-anak.
Multicultural education is an idea, an educational reform movement, and a process whose major goal is to change the structure of educational institutions so that male and female students, exceptional students, and students who are members of diverse racial, ethnic, and cultural groups will have an equal chance to achieve academically in school (Banks, 2005:9)

Banks (2002:1-3) menyatakan bahwa tujuan pendidikan multikultural mencakup: membangun pemahaman individu mengenai kehidupannya dari perspektif kultural dan etnis orang lain yang dapat menjadi arahan dalam berperilaku, memberikan pengalaman belajar yang menggambarkan berbagai kultur dan budaya orang lain, membantu individu dengan penyediaan berbagai pengetahuan, keterampilan dan sikap yang dibutukan untuk hidup dalam arus budaya utama dan dalam arus lintas budaya, dan menghilangkan tindakan diskriminasi yang individu atau masyakat alami karena perbedaan fisik, ras dan karakteristik budaya. Sebagai suatu ide, pendidikan multikultural berusaha untuk menciptakan kesempatan pendidikan yang sama untuk semua peserta didik dengan mengubah seluruh lingkungan sekolah agar merefleksikan kelompok-kelompok dan budaya-budaya yang beragam dalam suatu masyarakat dan dalam suatu negara.

As an idea, multicultural education seeks to create equal educational opportunities for all students, including those from different racial, ethnic, and sosial-class groups. Multicultural education tries to create equal educational opportunities for all students by changing the total school environment so that it will reflect the diverse cultures and groups within a society and within the nation's classrooms (http://education.washington.edu/cme/view. htm). 
Secara lebih rinci, James A. Banks (2002:12; 2007:83) menjelaskan bahwa dalam mengimplementasikan pendidikan multikultur dapat dilakukan dengan menekankan pada lima dimensi yang sekaligus merupakan tujuan pendidikan multikultural, yang mencakup:

1. Content integration (integrasi kruikulum). Pendekatan in mengembangkan muatan kurikulum (kegiatan, atau program) dengan memasukan informasi-informasi atau faktafakta dari dan mengenai berbagai kebudayaan untuk menjelaskan prinsip, teori maupun konsep-konsep yang terkait dalam proses pendidikan multikultural kepada peserta didik atau kelompok sasaran.

2. The knowledge contruction process (proses konstruksi pengetahuan). Proses pendidikan merupakan upaya pendidik membantu peserta didik untuk memahami bagaimana pengetahuan dibentuk dan bagaimana pengetahuan tersebut dipengaruhi oleh ras, etnis, gender dan posisi kelas sosial seseorang individu dan kelompok.

3. Prejudice reduction (pengurangan prasangka). Pendekatan ini menekankan pada proses pembelajaran yang dapat mengeliminir berbagai bias dan prasangka antar pendidik dengan peserta didik atau antar peserta didik. Melalui pembelajaran multikultural diharapkan terbangun pemahaman positif, terbangun wawasan untuk mengenal, mengetahui sekaligus mengalami pertautan antar karakteristik, serta dan dapat melakukan pemecahan masalah.
4. Equity pedagogy (pedagogi yang setaral). Pendekatan ini menekankan pada persamaan dan kesetaraan layanan pendidikan pada semua warga masyarakat. Proses pendidikan yang dilakukan sedapat mungkin memfasilitas semua gaya belajar peserta didik dari beragam kultur dan menumbuhkan kebersamaan dan kerja sama.

5. An empowering school culture and sosial culture (memberdayakan kultur sekolah dan masyarakat). Pendekatan ini digunakan untuk memberdayakan semua pihak baik guru, sekolah, maupun masyarakat untuk menciptakan budaya keadilan baik melalui kegiatan rekreasi, olah raga, dan kegiatan lainnya. Kultur saling bekerjasama dibangun berdasarkan pada consensus dan kepentingan bersama.

Pengembangan pendidikan multikultural tidak hanya dalam konteks pembelajaran di lembaga pendidikan namun juga dalam konteks kehidupan masyarakat luas. Penyelenggaraan pendidikan multikultural semestinya menjadi tanggung jawab semua pihak yang memiliki tanggung jawab karena pada dasarnya pendidikan menjadi tanggung jawab bersama. Undang-Undang RI No. 20 Tahun 2003 tentang Sistem Pendidikan Nasional pasal 54 menyatakan bahwa semua lapisan masyarakat dapat berpartisipasi dalam penyelenggaraan pendidikan. Keberhasilan pembangunan pendidikan bukan menjadi tanggung jawab pemerintah semata, melainkan menjadi tanggung jawab bersama tiga pilar pelaksana pembangunan pendidikan yaitu pemerintah, masyarakat dan keluarga. Dalam kaitan ini, masyarakat memiliki kewajiban dan hak untuk 
merencanakan, melaksanakan, dan membina serta mengembangkan berbagai upaya edukatif. Walau disadari bahwa penyelenggaran pendidikan sering kurang mendapatkan partisipasi masyarakat yang tinggi disebabkan sikap dan perilaku warga masyarakat yang tidak kooperatif dan apatis, kurang tersedia ruang untuk menyampaikan pesan atau pikiran terhadap kebijakan/kepentingan yang ada, dominasi kelompok tertentu, dan sistem sosial yang membatasi setiap warga masyarakat untuk berkembang.

\section{Fungsi Pemimpin Informal menuju Masyarakat Harmonis}

Salah satu pihak yang seharusnya dapat berpartisipasi aktif secara optimal dalam mendidik individu maupun masyarakat untuk lebih menjadi masyarakat yang terbuka, toleran, dan tidak diskriminatif adalah para pemimpin informal. Mereka adalah individu-individu yang memiliki fungsi strategis dalam pengembangan masyarakatnya mengingat di dalam diri pemimpin terdapat kekuatan mempengaruhi para pengikutnya untuk mencapai tujuan bersama atau dengan kata lain dalam diri seseorang terdapata kapasitas kempemimpinan (leadership). Konsep kepemimpinan dimaknai beragam oleh para ahli. Northouse (2007:3) menyatakan bahwa suatu proses dimana seorang individu mempengaruhi kelompok atau individu lain untuk mencapai tujuan. Senada dengan pendapat Hemling \& Coons (1957) bahwa kepemimpinan adalah perilaku individual yang mengarahkan aktivitas suatu kelompok untuk mencapai tujuan bersama (Yukl, 2006:5).

Terkait definisi kepemimpinan di atas, pemimpin informal dapat pahami sebagai seseorang yang dalam penentuan dirinya menjadi seorang pemimpin dikarenakan kepemilikan faktor-faktor atau sifat-sifat (traits) tertentu yang terdapat dalam pribadinya. Karakteristik dimaksud mencakup kepememilikan intelegensi yang tinggi, kepercayaan pada diri sendiri yang baik, keinginan dan kemampuan untuk bertindak lebih maju atau berpestasi, dapat dipercaya dan memiliki kejujuran, dan menyenangkan dalam berhubungan dengan lingkungan sosialnya (Northouse, 2007:19).

Dalam konteks pengembangan pendidikan multikultural, pemimpin informal menjadi kelompok strategis dalam menyampaikan ide-ide pembaharuan kepada masyarakatnya, yaitu pembaharuan menuju masyarakat demoratis dan harmonis. Pendidikan multikulural sebagai upaya pembaharuan dalam dunia pendidikan perlu dipahami, dihayati, dan diaplikasikan baik oleh agent pemberdayaan maupun kelompok sasaran pemberdayaan sehingga gerakan pembaruan ini dapat berjalan dengan proporsional karena berpijak pada consensus dan rasa memiliki bersama. Oleh karena itu, seorang pemimpin informal perlu menjalankan fungsinya dengan sebaik mungkin dan berpedoman pada hasil kinerja unggul.

Mengacu pada pendapat Banks (2002:30) bahwa pengembangan pendidikan multikultural dapat dilakukan dengan empat pendekatan yaitu: pendekatan kontribusi, pendekatan adiktif, pendekatan transformasi, dan pendekatan aksi sosial. Keempat pendekatan tersebut menjadi pemikiran untuk mengungkapkan fungsi-fungsi pemimpin informal dalam pengembangan pendidikan multikultural di masyatakat. 


\section{The Contributions Approach}

Melalui pendekatan kontribusi ini, pemimpin informal bertindak sebagai orang yang memberikan pemahaman atau informasi mengenai berbagai element-element yang ada di masyarakat yang dapat mengembangkan pemahaman masyarakat tentanga keberagaman. Pemimpin informal memberikan informasi kepada warga masyarakat mengenai hari libur keagamaan, para tokoh masyarakat yang berjasa dalam menjaga keutuhan masyarakat, dan element-element kebudayaan lainnya.

Dalam konteks ini, pemimpin informal dapat berperan sebagai penyampai keberhasilan, seorang pemimpin informal dituntut untuk dapat mempengaruhi dan memotivasi warganya melalui penyampaian-penyampaian cerita-cerita atau kisah-kisah kehidupan yang bermakna. Perjalanan-perjalanan seseorang atau masyarakat tertentu yang dipandang unggul dan berhasil, memiliki semangat kerja keras dan pengorbanan tinggi dapat dijadikan materi untuk mempengaruhi warga masyarakat lain. Misal, kisah perjuangan Mahatma Ghandi di India dengan perilaku perjuangan kemerdekaan tanpa kekerasannya, Nelson Mandela dengan perlawanan terhadap politik aparteide, atau tokoh-tokoh sosial-keagamaannya. Melalui kisah-kisah berbobot tersebut, warga masyarakat di lingkungan sosialnya akan dapat mengambil pelajaran-pelajaran penting, mencontoh dan berusaha menerapkannya dalam kehidupan sehari-hari. Proses imitasi menuju internalisasi nilai dan perilaku positif diharapkan dapat terbentuk. Penyampaian kisah-kisan bermanfaat perlu dilakukan oleh seorang pemimpin informal dengan menggunakan media komunikasi baik langsung maupun tidak langsung secara terbuka/dialogis, intens berulang-ulang, dan menggunakan bahasa-bahasa yang dapat dengan mudah dipahami warga masyarakat.

\section{The Additive Approach}

Dalam pendekatan ini materi, konsep, tema, dan perspektif ditambahkan ke program atau kegiatan tanpa mengubah struktur dasarnya. Artinya pemimpin informal dapat memberikan berbagai pemahaman yang baik mengenai keberagaman, keharmonisan dan pengembangannya dalam berbagai kesempatan yang ada di masyarakat. Pemimpin informal dapat menggunakan pertemuan-pertemuan baik level dusun/kampong, pemerintahan desa, maupun kecamatan; pertemuan rutin maupun incidental, untuk menanamkan konsep-konsep kesetaraan sosial yang menjadi harapan bersama. Literatur mengenai mengenai keberagaman (mutlkultural) dapat disampaikan kepada warga masyarakat untuk meningkatkan pemahamannya. Tentunya, pemimpin informal juga perlu menyadarkan bahwa warga masyarakat budaya belajar sehingga akhirnya mereka memiliki kemampuan literasi terhadap berbagai etnik, dan cultural yang berbeda (literasi budaya).

Terkait dengan ini, tentunya seorang pemimpin informal harus well-informed terhadap berbagai persoalan yang dapat bermanfaat bagi pelaksanaan kedua keterampilan tersebut. Pemimpin yang berpengetahuan, memungkinkan terjadi proses pembelajaran (transfer ilmu) kepada pengikutnya dimana dirinya akan menjadi seseorang yang dipandang dapat dimintai pendapat, wawasan dan pemikiran mengenai suatu persoalan, dan menjadi sumber belajar bagi pengikutnya. Seorang pemimpin 
masyarakat perlu memiliki pengetahuan mengenai paradigma utama, konsep utama, kultur dan sejarah, dan pedagogis dalam penyelenggaraan pendidikan multikultural.

\section{The Transformation Approach}

Pendekatan ini menekankan pada perubahan paradigm atau sudut pandang warga masyakat, yaitu paradigman untuk melihat berbagai konsep, isu, dan masalah dari perspektif etnik yang beragam. Mendasarkan pada pemikiran ini, pemimpin informal perlu memiliki kemampuan membelajarkan warga masyarakat agar mengubah paradigmanya yang semula mono-perspektif menjadi multiperspektif terhadap suatu persoalan atau kelompok lain. Pemimpin perlu menjadikan warga masyarakat memiliki paradigma yang sesuai dengan keharmonisan masyarakat.

Proses penyadaran diharapkan dapat mengubah persepsi atau cara pandang warga masyarakat yang salah terhadap lingkungan dirinya dan lingkungan masyarakat atau kelompok lain. Proses penyadaran dapat dilakukan dengan pendekatan pembelajaran dialogis-rekonstruktif atau pembelajaran transformatif. Menurut Mezirow (200:7-9) bahwa belajar transformative adalah proses yang mana individu-individu merubah kerangka pikir yang sudah ada, terjadi melalui proses refleksi krisis yang difasilitasi oleh dialog terbuka dalam kondisi yang nyaman, saling menghargai, dan saling membelajarkan. Melalui penyadaran atau conscientization menurut istilah Freire (Jana Noel, 2000:211), pemimpin informal diharapkan mampu mengembangkan warga masyarakat untuk mengingat kembali, memahami kembali, merenungkan kembali secara kritis dan selanjutnya merefleksikan kembali apa yang sudah dialami; keberhasilan dan kegagalan mana saja yang dialami; dan kekuatan apa yang dimiliki. Penyadaran dilakukan guna memerikan pemahaman kepada warga masyarakat mengenai realita yang terjadi dalam lingkungannya, mampu mengidentifikasi kebutuhan atau permasalahan yang dihadapi, dan mengajak mereka untuk mencari alternative solusi yang tepat demi memperbaiki mutu kehidupannya.

Proses penyadaran yang dilakukan pemimpin informal akan terjadi transformasi kesadaran diri (Zamrani, 2011:153) dari setiap warga masyarakat. Kesadaran diri ini mencakup bahwa seseorang harus: a) berfikir kritis mengapa dirinya tidak mau dan tidak mampu berfikir kritis; b) menyadari dirinya anti ketidakadilan; c) menyadari bahwa ketidakadilan terjadi bersifat sistemik; d) mewujudkan proses yang mengkaji berbagai kultur yang ada dan mencintai keberagaman; e) menyadari bahwa tidak dapat menghindari dari ketidaknyamanan karena pendirian sendiri; f) berorientasi kesetaraan; g) aktif berusaha dalam proses pemberdayaan; dan h) menyadari bahwa pendidikan (multicultural) atau pemberdayaan bersifat komprehensif, tidak sekadar tambal sulam.

Penyadaran dapat dilakukan menggunakan pendekatan berbasis pengalaman (experiential based approach) baik pengalaman atau masalah yang telah, sedang dihadapi atau potensial dihadapi. Pengalaman dimaksudkan untuk menghubungkan apa yang dipikirkan dengan yang terjadi di masyarakat. Warga masyarakat, tentunya bersama para pemimpin informal, mengkritisi berbagai pengalaman atau kenyataan yang ada di masyarakat seperti 
kebijakan pemerintah yang kurang relevan, tingginya angka kemiskinan, pengangguran dan kesehatan yang buruk, terjadinya disintegrasi sosial, tindakan dekadensi moral, perlakukan tindak kekerasan terhadap perempuan, diskriminasi atas nama agama, human trafficking, penyediaan infrastruktur sosial yang timpang, dsb.

Pengalaman yang diberikan pemimpin informal untuk penyadaran pastinya pengalaman yang menarik, menantang, dan sesuai dengan karakteristik masyarakat yang dipimpinnya. Melalui interaksi dengan pengalamanpengalaman (experiences) baru, pemimpin informal diharapkan membentuk pemahaman dan nilai-nilai baru yang mengarah pada perbaikan diri warga masyarakat (Illeris, 2004). Pengalaman ini akan menjadi instrumen yang penting di dalam menjalani proses belajar selanjutnya. Bentuk-bentuk pemberian pengalaman belajar yang dapat dilakukan oleh pemimpin informal antara lain: penyuluhan rutin yang disepakati bersama, membuka forumforum kajian di masyarakat, dan pemanfaatan media massa. Selain itu, pemberian pengalaman perlu dilakukan dengan menekankan pada pandangan bahwa warga masyarakat memiliki kemampuan untuk belajar dan mengembangkan dirinya; didukung oleh terciptanya proses interaksi edukasi yang setara (equity pedagogy) dan dialog yang murni dalam proses penyadaran masyarakat.

\section{The Sosial Action Approach}

Pendekatan ini menggabungkan pendekatan transformasi dengan kegiatan untuk berjuang untuk perubahan sosial. Warga masyarakat tidak hanya diperintahkan untuk memahami dan mempertanyakan isu-isu sosial, tapi juga melakukan sesuatu yang penting tentang hal itu. Pendekatan ini menekankan pada peran aktif semua warga masyarakat untuk berpartipasi dalam mewujudkan masyarakat harmonis melalui tindakan-tindakan nyata. Pemimpin informal mengajak dan bersamasama warga masyarakat melakukan berbagai tindakan pemberdayaan. Warga masyarakat dapat mengkritisi berbagai kebijakan pemerintah yang merugikan, menyampaikan pendapat/kritik secara bebas dan normative dalam berbagai media atau kesempatan publik, dan melakukan tindakan preventif, advokasi, edukasi ataupun rehabilitas pada warga masyarakat yang dipandang menerima perlakukan tidak adil. Misalnya program pengembangan masyarakat miskin, pengembangan bantuan sosial kemanusian, pengembangan pendidikan baik formal maupun nonformal yang dapat diakses oleh lapisan masyarakat, program pendampingan pada korban-korban tindakan kekerasan dan konfliks dsb, perlu direncanakan dan dikembangkan oleh para pemimpin formal.

Pemimpin informal memiliki kewajiban untuk mendesain berbagai program pemberdayaan masyarakat sebagai solusi untuk mengatasi permasalahan yang dihadapi dalam kehidupan bermasyarakat, dimana programnya mendapat dukungan dari pengikutnya. Dalam hal ini, pemimpin informal perlu menjadi orang yang berfungsi sebagai orang yang memililiki keterampilan mengatasi masalah atau problem solving skills (Nothouse, 2007:4). Kemampuan ini mencakup kemampuan mendefinisikan permasalahan yang dihadapi, mengumpulkan informasi yang terkait masalah, merumuskan pemahaman baru mengenai masalah, dan merumuskan rencana untuk mengatasi masalah. 
Dan juga, pemimpin informal perlu menyadari bahwa masalah yang dihadapinya berbeda dengan masalah pada lingkugan sosial lainnya.

\section{Kapasitas Kultural Pemimpin Informal}

Keberhasilan melakukan pendekatanpendekatan di atas, sangat tergantung pada kualitas diri para pemimpin informal. Artinya, pemberdayaan masyarakat menuju masyarakat demokratis-humanis akan dapat tercapai apabila para pemimpin informal memiliki kapasitas cultural yang unggul. Kapasitas atau kompetensi (multi) cultural, yang dimaknai oleh Roger (2006) sebagai kemampuan menerjemahkan pengetahuan tentang perbedaan kultur dalam layanan yang penuh afektif dan peka, dan kesadaran mengenai identitas diri (yaitu identitas yang dicirikan oleh etnis, gender, orientasi seks, dll) serta bias-bias (Zamroni, 2011;155). Dengan istilah hampir sama, Zamroni (2011:157) menyatakan bahwa kompetensi cultural mencakup berbagai hal: a) kemampuan individu untuk menerima, menghormati, dan membangun kerja sama dengan siapa pun juga yang memiliki perbedaan-perbedaan dari dirinya; b) kompetensi cultural merupakan hasil dari kesadaran atau pengetahuan dan "bias cultural" yang dimilikinya sebagai factor yang mempengaruhi perbedaan kultur; c) proses pengembangan kompetensi cultural memerlukan pengembangan pengetahuan, keterampilan, sikap dan perilaku yang memungkinkan seseorang memahami dan berperilaku secara efesien dengan orang yang memiliki perbedaan kultur.

Senada dengan pendapat di atas, Blanks (2007:25) menegaskan bahwa individu harus memiliki pemahaman cultural identification, national identification, dan global identication. Pemimpin informal perlu memiliki pengetahuan untuk memahami dimensi atau karakteristik budayanya, sekaligus memiliki pengetahuan untuk memahami bagaimana budaya diri dan bangsanya berpengaruh kepada dan dipengaruhi oleh kehidupan bangsa lain, dan memahami bagaimana saling hubungan dan ketergantungan antara budaya dan masyarakat secara global.

Kompetensi cultural ini menurut Papadopoulos \& Lee (2003) dalam Zamrani (2011:157) dibentuk oleh factor pengetahuan, pemikiran kritis, kemampuan mengembangkan sesuatu, dan kemampuan praktis. Keempat hal ini tidak statisk melainkan dinamis terus bergerak, membentuk kompetensi cultural. Berikut gambar keterkaitan empat factor kompetensi cultural.

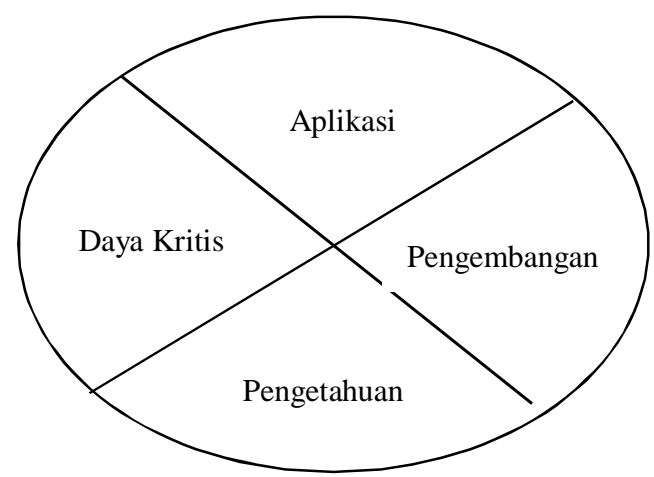

Gambar 1. Faktor Kompetensi Cultural

Guna mewujudkan pemimpin informal yang memiliki kapasitas cultural unggul, nampaknya pengembangan (pemberdayaan) pemimpin menjadi suatu tugas baru. Pemberdayaan pemimpin merupakan proses menjadikan kemampuan individu pemimpin menjadi lebih berdaya, lebih efektif, dan berorientasi unggul untuk mewujudkan masyarakat yang toleran, memiliki consensus dan mampu berpartisipasi baik. Proses pemberdayaan tentunya memerlukan intervensi dari berbagai pihak lain baik pemerintah, 
organisasi pemberdyaaan maupun individu. Dan pada pelaksanaan teknis pemberdayaan pemimpin informal dapat dilakukan dengan pendekatan individual maupun kelompok.

Proses mengembangkan pemimpin agar lebih berkompetensi cultural dapat dilakukan dengan memberikan bimbingan dan pendampingan secara kelompok. Artinya, para pemimpin dalam mengembangkan kemampuannya dilakukan secara bersama dalam suatu forum yang berfungsi untuk sharing pengetahuan antar setiap pemimpin masyarakat dan saling membelajarkan. Adanya kelompok bersama yang terbimbing, keinginan atau motivasi untuk berprestasi mengembangkan masyarakatnya masing-masing tercipta pada diri semua pemimpin dan belajar untuk saling menghargai, terbuka, dan berinteraksi secara dialogis dengan orang lain. Selain itu, melalu sarana ini diharapkan terbangun saling pengertian dan kerja sama yang baik antar para pemimpin informal.

Pengembangan kemampuan komunikasi efektif perlu bagi seorang pemimpin informal, mengingat berbagai karakteristik masyarakat yang heterogen. Kemampuan komunikasi perlu dibangun untuk membentuk keterampilanketerampilan dalam berhubungan dengan pengikut atau masyarakat yang berbeda secara kultur. Dengan adanya kemampuan komunikasi yang baik, seorang pemimpin informal akan dengan mudah menangkap pesan dari berbagai pihak dan terhindar dari ketidakpastian mengenai orang lain atau fakta tertentu, selain untuk mengembangkan kesetiakawanan, persahabatan, dan menghindari terjadinya konfliks. Adanya kemampun berkomunikasi, berbagai pesan pembaharuan akan mudah tersampaikan kepada kelompok sasaran, karena pemimpin dapat memilih sarana komunikasi bagaimana yang akan digunakan dan bagaimana karakteristik dan respon kelompok sasaran. Kemampuan komunikasi harus didukung oleh kebersediaan untuk melakukan dialog secara terbuka, dialog yang tidak semu, yang setiap orang memiliki hak yang setara dalam menyampaikan pemikiran dan harapanharapannya, dialog yang membebaskan (Freire, 1972). Membiasakan pemimpin untuk mengunjungi kelompok-kelompok sasaran pendidikan, atau bertemu dengan masyarakat lain secara langsung dan nyata dalam konteks kehidupannya memungkinkan terjadinya kemampuan-kemampuan berkomunikasi dengan baik.

Pemimpin informal sekaligus juga berfungsi sebagai manajer, yang mana seorang pemimpin perlu memiliki kemampuan dalam rencanakan tindakan, memobilisasi sumberdaya, dan melakukan kegiatan evaluasi terhadap implementasi pembaharuan.Seorang pemimpin informal harus dapat berfikir kreatif dalam mengelola kehidupan bermasyarakat. Pemikiran-pemikiran rasional berbasis fakta harus dimiliki seorang pemimpin informal dalam menjalankan fungsinya di masyarakat. Seorang pemimpin harus mampu menganalisis berbagai peluang yang ada di lingkungannya guna dimanfaatkan untuk pembangunan masyarakat, bekerja secara professional sesuai dengan batasan-batasan yang dimilikinya, berani mengambil keputusan-keputusan strategis dalam mengenai kepentingan bersama, dan selalu memberikan arahan dan bantuan teknis kepada semua orang yang dipandang memerlukan bantuannya. Pengembangan kapasitas ini dapat 
dilakukan dengan memberikan berbagai fasilitas bimbingan dan konsultasi, pembentukan kelompok diskusi, pemanfaatan fasilitas media maya (internet), dan pelatihan-pelatihan.

\section{KESIMPULAN}

Pemimpin informal memiliki peran penting dalam menyukseskan pendidikan multikultural, karena mereka merupakan individu yang memiliki kedekatan emosional dengan masyarakat di lingkungannya, dan kemungkinan pengaruh untuk menyampaikan ide-ide dan/atau layanan pendidikan multikultural lebih cepat dan mudah diterima oleh warga masyarakat lain. Pengoptimalan fungsi pemimpin informal dalam pengembangan pendidikan multikultural perlu dilakukan mengingat pendidikan multikultural bukan hanya berlangsung dalam proses interaksi pembelajaran semata, namun dalam semua kehidupan sistem sosial masyarakat. Tentunya untuk keberhasilan menciptakan masyarakat yang demokratis dan berkeadilan sosial, kapasitas pemimpin informal yaitu kompetensi cultural menjadi keharusan untuk dikembangkan agar pelaksaan berbagai fungsi dan pendekatan pendidikan multikultural dapat berjalan secara efektif. Kapasitas yang baik akan menjamin proses perubahan kehidupan masyarakat yang efektif dapat tercapai.

\section{DAFTAR PUSTAKA}

James A. Banks. ( 2012). Multicultural educatin: Goals and dimensions. Diakses dari

http://education.washington.edu/cme/view .htm).
Blanks, James A.(2007). Education citizens in a multicultural society. New York: Teacher College Press.

Banks, James A. and Blanks, Cherry A. McGee. (2005). Multicultural education: Issues and perspectives. Hoboken NJ: John Wiely \& Sons, Inc.

Blanks, James A. (2002). An introduction to multicultural education. Boston: Allin and Bacon

Fagerlind, Ingemar. \& Saha, Lawerenc J. (1983). Education and national development. Oxpord: Pregamon Press.

Freire, Paulo. (1972). Pedagogy of the oppressed. Victoria: Penguin Books Ltd.

Illeris, Knud (2004). Three dimensions of learning. Florida: Krieger Publishing Company.

Mezirow, Jack. (2000). Learning as transformation. San Francisco: Jossey Bass

Noel, Jana. (2002). Notable selection in multicultural education. Connecticut: McGraw-Hill.

Northouse, Peter G. (2007). Ledership. Thousan Oaks: Sage Publications.

Puitt, Dean G. and Rubin Zeffrey Z. (2004). Teori konfliks sosial. Terjemahan oleh Helly P. Soetjipto. Yogyakarta: Pustaka Pelajar

Rummel. (2012). Understanding conflict and war. Diakses dari www.hawaii.edu

Sutoro Eko. (2004). Reformasi politik dan pemberdayaan masyarakat. Yogyakarta: APMD Press Yogyakarta.

Yukl, Gary. (2006). Leadership in organization. New Jersey: Person Prentice Hall.

Zamroni. (2011). Pendidikan demokrasi pada masyarakat multikultur. Yogyakarta: Gavin Kalam Utama.

Zamroni. (2011). Research on multicultural education: A reader. Yogyakarta: Graduate Program, The State Univesity of Yogyakarta. 